\title{
The Effect of the COVID-19 Pandemic on Healthcare Workers
}

\author{
Abdullah Murat Tuncer \\ Conley American University, Honolulu, USA \\ Email: muratatuncer@gmail.com
}

How to cite this paper: Tuncer, A. M. (2022). The Effect of the COVID-19 Pandemic on Healthcare Workers. Advances in Applied Sociology, 12, 29-33.

https://doi.org/10.4236/aasoci.2022.122003

Received: January 3, 2022

Accepted: February 8, 2022

Published: February 11, 2022

Copyright $\odot 2022$ by author(s) and Scientific Research Publishing Inc. This work is licensed under the Creative Commons Attribution International License (CC BY 4.0).

http://creativecommons.org/licenses/by/4.0/

\begin{abstract}
The coronovirus pandemic has not only been a health problem but has also caused social problems that are impossible to end in the short term. Especially the effects are very deep on health workers. Depression, anxiety, and fear of the future are most common feelings among the people and health workers. Health system and health policy must figure out pandemic as a social problem at the same time.
\end{abstract}

\section{Keywords}

Pandemic, Coronovirus, Health Workers, Women Health Workers, Gender Discrimination

\section{Introduction}

As from March 2020, when the World Health Organization (WHO) declared a pandemic, as of July 23, 2021, 17.30, in reference to hourly basis information announced by WHO on the "COVID-19 Dashboard", 192,300,000 people had contracted COVID-19 and 4,137,000 people had died from the same illness. Since the spread of COVID-19 is extremely rapid, even if the death rate is about $3 \%$, the inability to provide adequate health services has emerged as a fundamental problem, due to its locking down the health systems of countries.

Despite the rapid completion of vaccine studies, the start of vaccination took about a year.

In the treatment, screening, the work of filiation teams and vaccination, the main responsibility has fallen upon the health workers.

Confusion of information has been one of the most serious challenges during the pandemic. Regarding official documents, in relation to the exact number of health workers have lost their lives due to COVID-19, the data originating from 
the Turkish Medical Association (TTB) and from the Ministry of Health do not match. TTB documents show that 132 doctors have already died, while on active duty in our country. The figures given in May 2021 also reveal that more than 400 health workers lost their lives due to COVID-19. The difficulty of working conditions for health professionals, the stress of contact with the disease together with the cancellation of leave, the psychological pressures caused by COVID-19 not being considered as occupational disease, the conflict of roles have had negative effects on health professionals (Turkish Medical Association Report 2021 and Turkish Nurses Association 12 report 2020 and 2021).

Academics, who have publicly promoted debates, in the media, that even many doctors have difficulty to understand, have caused the mental state being already tense and tensions to worsen, the subject to be taken in different directions with contradictory information, and therefore, conflicting opinions about the disease and vaccine. The fact that the sources provided conflicting information has created mistrust both in health workers and non-healthcare professionals.

\section{Challenges of the Health System}

When analysed from the standpoint of health sociology, the poor get poorer and the rich get richer with neo-liberal policies. International capitalist powers invest if they make money from disease prevention. If they earn money from the spread of a disease, they support approaches in which the disease will spread out.

In this regard, the incomes from vaccines and tobacco are the most conspicuous examples. Tobacco producers cause 8 million deaths every year. COVID-19 has killed 2 million people a year. Those who have made money from tobacco have also acquired a significant surplus earnings from vaccine production. Unfortunately, there are no more scientists like Robert Koch and Pastor who will donate the license of the treatment they found to humanity. While the health transformation program having been carried out, since 2002 has been successful in many fields, unfortunately it has been unfavorably affected by globalization.

Because of our health system, which has been unable to produce even the smallpox and BCG vaccines we have produced since the time of the Ottoman Sultan Mahmut, the Second, and the time of Dr Refik Saydam, respectively; we have had to pay serious fees for the vaccines and there have been difficulties in vaccination process, for economic reasons and due to severe supply chain delays. Our intensive care beds, despite their significant numbers compared to Europe, have been troubled by the rapid spread of COVID-19, and the quantity of health workers, being already quite inadequate, has remained insufficient immediately. The requirement of intensive care in the course of the disease is not only limited to equipment and tools, but also medical personnel equipped with serious intensive care trainings and experiences are needed. This deficit is not a situation that can be compansated within a short time. For all these reasons, health workers have suddenly experienced having a burden on their shoulders. Health person- 
nel have had to continue their intensive work even without taking their annual leave, because the national and local administrative units failed to organise appropriate time tables to Schedule personnel's leave. Leave were not met adequately on time. Since the legal arrangements by the government have not been accomplished over time, Violence against health workers could not be prevented. The tense atmosphere has exacerbated the violence. Due to the inability to make legal arrangements in a timely manner, violence against health workers could not be prevented. The tense atmosphere has exacerbated the violence. It has also increased the extent of already existing gender discrimination and violence against women.

\section{Direct and Indirect Effects of the Pandemic}

Despite having a very low death rate compared to other respiratory infections with a death rate of $3-6$ percent, the heaviest burden of COVID-19 is that it locks up the health system, as it can spread very rapidly and affect a heavy mass of people within a very short time.

The pandemic has caused serious problems in all countries over the world, both in human resources, medical equipment and bed capacities. The spread of social fear as well as increased awareness during the WHO's pandemic declaration and public information has made the disease a "stigmata" (Shreffler et al., 2020: p. 21).

In addition to these direct effects of COVID-19 disease, which is the most obvious symptoms of decreased respiratory function, breathing difficulties and fever, job loss and therefore economic difficulties have created heavy burdens. Although it has a very low death rate compared to other respiratory tract infections with a death rate of 3 - 6 percent, the heaviest burden of COVID-19 is that it locks the health system, as it can spread very quickly and affect a dense mass in a very short time. The pandemic has created a serious problem in all countries in the world, both in terms of human resources, medical equipment and bed capacities. The spread of social fear as well as the increase in awareness during the WHO's declaration of the pandemic and informing the public has made the disease a "stigmata" (Shreffler et al., 2020: p. 21). These direct effects of the COVID-19 disease, which are the most obvious symptoms of decreased respiratory functions, difficulty in breathing and fever, as well as job loss, and thus economic problems have created heavy burdens. This situation forced the health workers, who had to constantly encounter the disease, to take intensive measures, the working hours increased, and the weight of the already existing working conditions due to the workload increased once again. The ban on resignation and taking annual leave have created a separate psychological burden and weariness (Ofori et al., 2021).

Apart from their own health, the suspicion of carrying the disease into their homes and families has caused a conflict of roles and excessive emotional pressure. Not accepting companions with sick people and isolation conditions have 
made the work of health workers more challenging (Isma'il Tsiga-Ahmed et al., 2021: p. 10).

In the report prepared by the Turkish Medical Association, it is stated that "providing the basic needs of health workers, preparing safe working environments for them and transforming the individual fight against the epidemic into a social, well-organized struggle, and paying the health workers equally and equitably for their efforts on wages will help to solve the source of the mental problems that arise from the epidemic" (Güvenç \& Baltac1, 2020). In a study conducted by the Nurses Association, many situations namely, the alarming increase in need for nurses being faced, making nurses work outside of nursing job descriptions, the problems in maintaining the nursing education in a qualified way, the care problem of children whose parents are health workers, being unable to iron out worries and anxieties of the pregnant health workers, and encountering problems in accessing personal protective precaution equipment are shown as the main sources of problems and concerns. The Turkish Nurses Association has prepared 12 reports on this issue to the Ministry of Health and explained the problems and the solutions in this regard (Çelik et al., 2020).

We can assess the effects, such as; depression, anxiety and worry, boredom, disintegration, self-alienation, uneasiness in human relations as indirect effects of the pandemic. In addition, economic contraction, anxiety and increased tension have caused tensions between the patient-patient's relatives and the health workers. This tension has also increased among health workers, especially with pre-existing gender inequality, violence against women and mobbing have increased considerably. The reports prepared by TTB and the Turkish Nurses Association emphasize both violence against health workers and violence and discrimination against female health workers (Demir, 2021).

In a qualitative study carried out to understand the gender-based problems in relation to women's work-life problems and to what extent the COVID-19 pandemic has deepened these problems, and what other effects the pandemic has brought about on female health workers; it has been demonstrated that mobbing, violence and sexism against female health workers have increased, women's home, elderly and child responsibilities are not sufficiently shared by their spouses (Kavas \& Develi, 2020; Collins et al., 2020).

\section{Conclusion}

The pandemic has increased the feelings of depression, anxiety, worry, and disorganization on healthcare workers, but unfortunately, necessary precautions have not been able to be taken in this regard.

When we oversee the world in general, it saying that there are successful countries taking measures in the fight against the pandemic and preventing the health workers from being affected is not sensible. However, the issue of becoming more or less successful can be talked of. The positive effect of the pandemic has been the change in the perception of medicine as a social institution and health 
as a social phenomenon.

\section{Conflicts of Interest}

The author declares no conflicts of interest regarding the publication of this paper.

\section{References}

Çelik, S. Ş., Özbaş, A. A., Çelik, B., Karahan, A., Bulut, H., Koç, G., Aydın, F. Ç., \& Özleyen, Ç. Ö. (2020). COVID-19 Pandemi Süreci. Türk Hemşireler Derneği, Koç Üniversitesi Hemşirelikte Eğitim ve Araştırma Dergisi, 279-283.

Collins, C., Landivar, L. C., Ruppander, L., \& Scarborough, W. J. (2020). COVID-19 and Gender Gap in Work Hours. Gender, Work and Organizations, 28, 101.

https://doi.org/10.1111/gwao.12506

Demir, Ö. (Ed.) (2021). COVID-19 ve sosyal politika; Pandemi sürecinde yaşanan SosyoPolitik sorunlar. Ankara: Son Çă̆ Yayıncıllk.

Güvenç, R., \& Baltacı, E. (2020). COVID-19 ve Sağlık Çalışanlarının Ruh Sağlığı. Ankara: Türk Tabipler Birliği, COVID-19 Altıncı Ay değerlendirme Raporu.

Isma'il Tsiga-Ahmed, F., Gboluwaga Amole, T., Maiyaki Musa, B., Muhammad Nalado, A., Agoyi, A. B., Shehu Galadanci, H., \& Salihu, H. M. (2021). COVID-19; Evaluating the Knowledge, Attitude on Preventive Preactices of Healthcare Workers in North Nigeria. International Journal of Maternal and Child Health and AIDS, 10, 88-97. https://doi.org/10.21106/ijma.418

Kavas, N., \& Develi, A. (2020). Çalışma Yaşamındaki Sorunlar Bağlamında COVİD-19 Pandemisinin Kadın Sağlık Çalışanları Üzerindeki Etkisi. Uluslararası Anadolu Sosyal Bilimler Dergisi, 4, 84-112.

Ofori, A. A., Osarfo, J., Agbeno, E. K., Manu, O. D., \& Amoch, E. (2021). Psycological Impact of COVID-19 on Health Workers in Ghana; A Multicentre Cross Sectional Study. SAGE Open Medicine, 9, 1-10. https://doi.org/10.1177/20503121211000919

Shreffler, J., Petrey, J., \& Huecker, M. (2020). The Impact of COVID-19 on Healthcare Workers Wellness: A Scoping Review. Western Journal of Emergency Medicine: Integrating Emergency Care with Population Health, 21, 1059-1066.

https://doi.org/10.5811/westjem.2020.7.48684 